\title{
Polymerase chain reaction of enterococcus faecalis and candida albicans in apical periodontitis from Turkish patients.
}

\author{
Aysin Dumani ${ }^{1}$, Oguz Yoldas ${ }^{2}$, Sehnaz Yilmaz ${ }^{1}$, Fatih Koksal ${ }^{3}$, Begum Kayar ${ }^{4}$, Beril Akcimen ${ }^{4}$, Gulsah \\ Seydaoglu 5
}

${ }^{1}$ DDS, PhD. Assistant Professor, Cukurova University, Faculty of Dentistry, Department of Endodontics.

${ }^{2} \mathrm{DDS}, \mathrm{PhD}$. Professor, Cukurova University, Faculty of Dentistry, Department of Endodontics.

${ }^{3} \mathrm{MD}, \mathrm{PhD}$. Professor, Cukurova University, Department of Microbiology.

${ }^{4}$ DDS, PhD. Research Asistant, Cukurova University, Department of Microbiology.

${ }^{5} \mathrm{MD}$, PhD. Associated Professor, Cukurova University, Department of Biostatistic.

Correspondence:

Çukurova Üniversitesi

Diş Hekimliği Fakültesi

Balcall Adana TURKEY

e-mail:adumani@cu.edu.tr

\begin{abstract}
Aim: The aim of this study was to determine the frequency of two important pathogenic microorganisms associated with endodontic infections, Enterococcus faecalis and Candida albicans, in root canal samples from patients with necrotic pulps or failed canal therapy by polymerase chain reaction method.

Methodology: Microbial samples were obtained from 117 teeth with necrotic pulp tissues and 114 teeth with failed endodontic treatment.

Results: E.faecalis were identified in $16 \%$ of the necrotic and $10 \%$ of the retreated root canal infections by PCR. C.albicans genome were identified in $20 \%$ and $11 \%$ of the necrotic and retreated root canal infections, respectively, by PCR. The frequencies of microbiota were not statistically different between necrotic and retreatment groups ( $\mathrm{p}$ $>0.05$, chi squared test).

Conclusions: PCR analysis of teeth with periapical lesions revealed that E.faecalis was found in fewer patients than in previous studies. The C.albicans prevelance was consistent with previous reports. No statistical difference was found between primary and secondary root canal infections for C.albicans or E.faecalis.
\end{abstract}

Key Words: Primary root canal infection, secondary root canal infection, E.faecalis, C.albicans. 


\section{Introduction}

The most important factor associated with endodontic failure is the presence of persistent microbial infection in the root canal system (1). In most studies, the root canal microbiota of teeth with failed endodontic treatment is different from the flora found in untreated teeth (2-4). Necrotic root canals are typically polymicrobial, with nearly equal proportions of Grampositive and Gramnegative bacteria, and are dominated by anaerobic bacteria. Additionally, anaerobes are, in many cases, accompanied by microaerophilic and facultative bacteria (5). In contrast, the microbial flora in retreatments have been described as monoinfections or infections including a few Grampositive bacterial species, with approximately equal proportions of facultative and obligate anaerobes (4). Root-filled teeth with apical periodontitis microbiota contain Enterococcus spp. together with Streptococci, Lactobacilli, facultative bacteria, and anaerobic bacteria. Gram-negative enteric rods and yeasts have also been found in retreatment cases $(4,6)$.

In recent microbiological studies, increasing concern has arisen about Candida albicans (C.albicans) and Enterococcus faecalis (E.faecalis) in failed root canal treatments. E.faecalis can occur in primary root canal infections, especially in teeth with coronal leakage, although typically in low numbers (7) and also is the most common organism cultured from failed root canal therapy, with $12-90 \%$ prevalence $(8,9)$. This disparity in the composition of root canal microbiota can be related to differences in methodologies of studies, but may also be influenced by other factors, such as geographical effects (10). Bacteria may originate in the oral cavity and contaminate the root canal during treatment due to inadequate aseptic control or penetrate the root filling via coronal leakage after root canal treatment (11). Engström (12) found a direct relationship between the occurrence of enterococci in the oral cavity and that in the pulp space. Sedgley et al. (13) showed that E.faecalis could be isolated from $5 \%$ and $55 \%$ of tongue samples, using culture and PCR methods, respectively. Viable enterococci are frequently found in fermented foods for raw consumption, such as cheese and meat, as well as in vegetables and olives $(14,15)$. E. faecium is the main species found in meat, whereas E.faecalis predominates in cheese $(14,15)$.

Fungi were reported in $2-21 \%$ of teeth with primary endodontic infections by researchers using culture and molecular methods (16). Fungi have been more commonly found in the root canals of obturated teeth with apical periodontitis, compared with necrotic root canals. The presence of yeasts in treatment-resistant cases ranges from 3 to $18 \%$ as shown by culture and PCR techniques $(8,16)$. Candida species are known to be present in the oral cavity (16) and C.albicans is the most commonly isolated fungal species in the oral cavity $(30-45 \%$ )
$(16,17)$.

Recent studies using molecular methods have demonstrated that the microflora associated with endodontic infections are more diverse than was previously reported from studies using conventional culture methods $(18,19)$. Molecular methods are typically faster, easier, and more precise than culturing methods. PCR is so sensitive that it can detect the presence of fewer than 10 bacteria in a sample. A major disadvantage of molecular methods is that organisms cannot be cultivated, so whether the cells are viable remains unknown (20).

The aim of this study was to investigate the presence of E.faecalis and C.albicans in endodontic infections using PCR.

\section{Material and Methods}

Patients who were referred to Cukurova University Dental School for endodontic treatment or retreatment were included. Medical and dental histories were obtained from each patient. Age, gender, tooth type, pulp status, pain, history of previous pain, tenderness to percussion, pain on palpation, mobility, presence of a sinus, presence of swelling, history of previous and present antibiotic therapy, periapical radiolucency and radiographic findings with PAI (21) index were recorded (Table 1). For necrotic teeth, an electric pulp test was conducted.

The study protocol describing specimen collection was approved by the Ethical Committee in Research of the Dental School of Cukurova University. Informed consent was obtained from all patients.

Microbial samples were obtained from 117 teeth of 100 patients with necrotic pulp tissues and 114 teeth of 70 patients with failed endodontic treatment. Control strains of E.faecalis (ATCC 97008) and C.albicans (ATCC 90028) were obtained from the culture collection at Refik Saydam Hıfzıssıhha Enstitüsü, Ankara, Turkey. Root Canal Sampling

Each tooth was cleaned with pumice and isolated with a rubber dam. Teeth that could not be fully isolated with a rubber dam were excluded from the study. A gingival barrier (OpalDam Light Cured Gingival Barrier, Ultradent) was used between the teeth and the rubber dam for each case. The tooth and surrounding field were cleaned with $35 \%$ hydrogen peroxide $\left(\mathrm{H}_{2} \mathrm{O}_{2}\right)$ and decontaminated with a $5 \%$ sodium hypochlorite $(\mathrm{NaOCl})$ solution. After disinfection, the coronal restorations were removed. After completion of the endodontic access with a sterile high-speed carbide bur, the tooth, clamp, and adjacent rubber dam were once again disinfected with 5\% $\mathrm{NaOCl}$ and then inactivated with sodium thiosulphate to avoid interference with the bacteriological sampling. For a control, a sterile cotton pellet was placed for $2 \mathrm{~min}$ in the pulp chamber to assess the efficacy of the disinfection procedure. Control pellet were taken to the microbiology laboratory for processing within $2 \mathrm{~h}$. Thiogluco- 


\begin{tabular}{|c|c|c|c|c|c|}
\hline & & \multicolumn{2}{|c|}{$\begin{array}{l}\text { Necrotic Teeth } \\
\text { (n:100 patients, } 117 \text { teeth) }\end{array}$} & \multicolumn{2}{|c|}{$\begin{array}{l}\text { Retreatment Teeth } \\
\text { (n:70 patients, } 114 \text { teeth) }\end{array}$} \\
\hline & & $\mathbf{n}$ & $\%$ & n & $\%$ \\
\hline \multirow[t]{2}{*}{ Age } & $\leq 45$ & 62 & 62 & 55 & 79 \\
\hline & $>45$ & 38 & 38 & 15 & 22 \\
\hline \multirow[t]{2}{*}{ Gender } & Male & 39 & 39 & 24 & 34 \\
\hline & Female & 61 & 61 & 46 & 66 \\
\hline \multirow{4}{*}{$\begin{array}{l}\text { Tooth } \\
\text { location }\end{array}$} & Maxilla & 80 & 68 & 65 & 57 \\
\hline & Mandibula & 37 & 32 & 49 & 43 \\
\hline & Anterior & 94 & 80 & 59 & 52 \\
\hline & Posterior & 23 & 20 & 55 & 48 \\
\hline \multirow[t]{2}{*}{ Symptoms } & Present & 55 & 47 & 48 & 42 \\
\hline & Absent & 62 & 53 & 66 & 58 \\
\hline \multirow[t]{2}{*}{ PAI } & $\leq 2$ & 22 & 18 & 33 & 29 \\
\hline & $>3$ & 95 & 82 & 81 & 71 \\
\hline \multirow[t]{2}{*}{ Sinus tract } & Present & 29 & 23 & 20 & 18 \\
\hline & Absent & 88 & 77 & 94 & 82 \\
\hline
\end{tabular}

Table 1. Characteristics of patients and necrotic teeth and retreatment teeth samples.

late medium samples were incubated at $37^{\circ} \mathrm{C}$ for $24 \mathrm{~h}$. If microbial growth was detected on the sterile control cotton pellet samples taken from the pulp chamber, the samples were disregarded.

For microbial sampling, No.15 Ktype file with the handle cut off was introduced to a level approximately 1 $\mathrm{mm}$ short of the tooth apex, based on diagnostic radiographs, with a discrete filing motion. If the root canal was dry, a small amount of sterile saline solution was introduced into the canal. Afterwards, three sterile paper were placed into the canal, with each left for $1 \mathrm{~min}$ for absorbing all the fluids present within them. These paper points were then transfered to cyro-tubes containing TE buffer and immediately frozen at $-20^{\circ} \mathrm{C}$.

Cases with failed endodontic treatments were sampled as follows. After plaque removal, isolation, and disinfection of the operative field as described aboved, coronal restorations were removed and the same disinfection protocol was used. Preexisting root canal fillings were removed using a Gates-Glidden drill and the apical material was retrived using Ktype files without the use of chemical solvents. Sterile saline solution was introduced into the canal to remove any remaning materials and to release the debris. The same procedure was used for the root canal sampling.

\section{DNA Extraction}

DNA extraction of samples was performed using the QIAamp DNA mini kit (Qiagen, Valencia, CA) according to the manufacturer's instructions. $100 \mu \mathrm{L}$ 's of each clinical sample was used for DNA extraction. Briefly, samples were thawed to $37^{\circ} \mathrm{C}$ for $10 \mathrm{~min}$ and vortexed for $30 \mathrm{~s}$. The microbial suspension was centrifugated for $10 \mathrm{~min}$ at $5000 \mathrm{~g}$ and the pellets were then resuspended in $180 \mu \mathrm{L}$ ATL buffer (Qiagen). Afterwards, $20 \mu \mathrm{L}$ proteinase $\mathrm{K}(20 \mathrm{mg} / \mathrm{ml})$ was added and samples were incubated for $3 \mathrm{~h}$ at $56^{\circ} \mathrm{C}$. Next, $200 \mu \mathrm{L}$ of ethanol was added and DNA was isolated by adding the lysate to the Qiagen columns as described by manufacturer. Finally, the total bacterial DNA was eluted with $200 \mu \mathrm{L}$ AE buffer (Qiagen). DNA extracts were stored at $-20^{\circ} \mathrm{C}$. Reference DNA from target bacteria (E.faecalis ATCC strain 97008 and C.albicans ATCC strain 90028) were also extracted in the same manner. They served as controls for the primers used in this study. The DNA concentrations in clinical samples and the concentrations of the referance DNA were determined by spectrophotometer measurement of the absorbance at $260 \mathrm{~nm}$.

\section{DNA Amplification}

A species-specific PCR assay with primers targeted to the 16S rRNA gene was done for E.faecalis and C.albicans. A pair of universal eubacterial primers that matches almost all bacterial 16S rRNA genes was used as a positive control for PCR reaction. It served to indicate the presence of bacteria in the clinical samples. The primers sequences of universal primer is F: 5'GAT TAG ATA CCC TGG TAG TCC AC-3' and R: 5'-CCC GGG AAC GTA TTC ACC G-3' (22). To identify enterococci species, enterococcal chromosomal DNA was amplified using the primers F: 5'-GTT TAT GCC GCA TGG CAT AAG AG-3' and R: 5'-CCG TCA GGG GAC GTT CAG-3' targeted to the E.faecalis 16S rRNA (23). Candidal chromosomal DNA was amplified using the 


\begin{tabular}{llll}
\hline & $\begin{array}{l}\text { Universal 16S } \\
\text { rRNA Primer (34) }\end{array}$ & E.faecalis (35) & C.albicans (36) \\
\hline Sequence $\left(\mathbf{5}^{\prime} \mathbf{- 3}^{\prime}\right)^{\mathbf{a}}$ & $\begin{array}{l}\text { GAT TAG ATA CCC TGG } \\
\text { TAG TCC AC }\end{array}$ & $\begin{array}{l}\text { GTT TAT GCC GCA TGG } \\
\text { CAT AAG AG }\end{array}$ & $\begin{array}{l}\text { GCC GGT GAC GAC GCT } \\
\text { CCA AGA GCT G }\end{array}$ \\
& $\begin{array}{l}\text { CCC GGG AAC GTA } \\
\text { TTC ACC G }\end{array}$ & $\begin{array}{l}\text { CCG TCA GGG GAC GTT } \\
\text { CAG }\end{array}$ & $\begin{array}{l}\text { CCG TGT TCA ATT GGG } \\
\text { TAT CTC AAG GTC }\end{array}$ \\
Size (bp) & $602 \mathrm{bp}$ & $310 \mathrm{bp}$ & $158 \mathrm{bp}$ \\
Denaturation & $95^{\circ} \mathrm{C} / 30 \mathrm{~s}$ & $94^{\circ} \mathrm{C} / 30 \mathrm{~s}$ & $95^{\circ} \mathrm{C} / 1 \mathrm{~min}$ \\
Annealing & $60^{\circ} \mathrm{C} / 1 \mathrm{~min}$ & $60^{\circ} \mathrm{C} / 1 \mathrm{~min}$ & $55^{\circ} \mathrm{C} / 30 \mathrm{~s}$ \\
Extension & $72^{\circ} \mathrm{C} / 1 \mathrm{~min}$ & $72^{\circ} \mathrm{C} / 1 \mathrm{~min}$ & $72^{\circ} \mathrm{C} / 1 \mathrm{~min}$ \\
Final extension & $72^{\circ} \mathrm{C} / 2 \mathrm{~min}$ & $72^{\circ} \mathrm{C} / 2 \mathrm{~min}$ & $72^{\circ} \mathrm{C} / 10 \mathrm{~min}$ \\
\hline
\end{tabular}

${ }^{a}$ The top primer is the forward primer, and the lower primer is the reverse primer.

Table 2. Oligonucleotide primer pairs used with PCR conditions

primers F:5'-GCC GGT GAC GAC GCT CCA AGA GCT G-3' and R: 5'-CCG TGT TCA ATT GGG TAT CTC AAG GTC-3' (24). PCR reaction used to assess the occurrence of all target bacteria was performed with 50 $\mu \mathrm{L}$ of reaction mixture containing $0.5 \mu \mathrm{M}$ of each specific primer, $2.5 \mathrm{mM} \mathrm{MgCl}, 0.2 \mathrm{mM}$ dNTP, $2.5 \mathrm{U}$ Taq polymerase (Qiagen), and $10 \mu \mathrm{L}$ extracted DNA. Amplification was carried out in a thermal cycler (Applied Biosystems 2720 Thermal Cycler, Singapore) with an initial denaturation step of $95^{\circ} \mathrm{C}$ for $2 \mathrm{~min}$ and followed by 36 cycles of a denaturation step at $95^{\circ} \mathrm{C}$ for $30 \mathrm{~s}$ and primer annealing step at $60^{\circ} \mathrm{C}$ for $1 \mathrm{~m}$, an extension step at $72^{\circ} \mathrm{C}$ for $1 \mathrm{~min}$, and a final step at $72^{\circ} \mathrm{C}$ for $2 \mathrm{~min}$ for Universal 16S r RNA primer. The temperature profile for E.faecalis included an initial denaturation step of $95^{\circ} \mathrm{C}$ for $15 \mathrm{~min}$ and followed by 35 cycles of a denaturation step at $94^{\circ} \mathrm{C}$ for $30 \mathrm{~s}$ and primer annealing step at $60^{\circ} \mathrm{C}$ for $1 \mathrm{~m}$, an extension step at $72^{\circ} \mathrm{C}$ for $1 \mathrm{~min}$, and a final step at $72^{\circ} \mathrm{C}$ for $2 \mathrm{~min}$. The temperature profile for C.albicans included an initial denaturation step at $95^{\circ} \mathrm{C}$ for $15 \mathrm{~min}$ and followed by 35 cycles of a denaturation step at $95^{\circ} \mathrm{C}$ for $1 \mathrm{~min}$ and primer annealing step at $55^{\circ} \mathrm{C}$ for $30 \mathrm{~s}$, an extension step at $72^{\circ} \mathrm{C}$ for $1 \mathrm{~min}$, and a final step at $72^{\circ} \mathrm{C}$ for $10 \mathrm{~min}$. (Table 2). For negative control ultrapure water was used.

PCR products were analyzed by $2 \%$ agarose gel (Seakem GTG agarose, FMC Bioproducts, Rockland, ME, USA) electrophoresis performed at $120 \mathrm{~V}$ in Tris-Borate EDTA buffer. The gels were stained with $0.5 \mu \mathrm{g} / \mathrm{mL}$ of ethidium bromide and visualized under ultraviolet light, and photographed with the Kodak Gel Logic 1500 Imaging System. We used a 100-bp DNA ladder digest (Invitrogen, Sao Paulo, Brasil) as a molecular weight marker. The data collected were statistically analyzed using SPSS (ver. 12.0; SPSS Inc, Chicago, IL). Catagorical variables between the groups were analyzed using the chisquared test or the McNemar test. Results are presented as $n(\%)$. All reported $p$ values are two-tailed.

\section{Results}

E.faecalis was identified in $19(16 \%)$ of 117 necrotic canals and $11(10 \%)$ of 114 re-treated canals and C.albicans was identified in $23(20 \%)$ and $13(11 \%)$ necrotic and re-treated canals, respectively by PCR analysis. (Fig. 1,

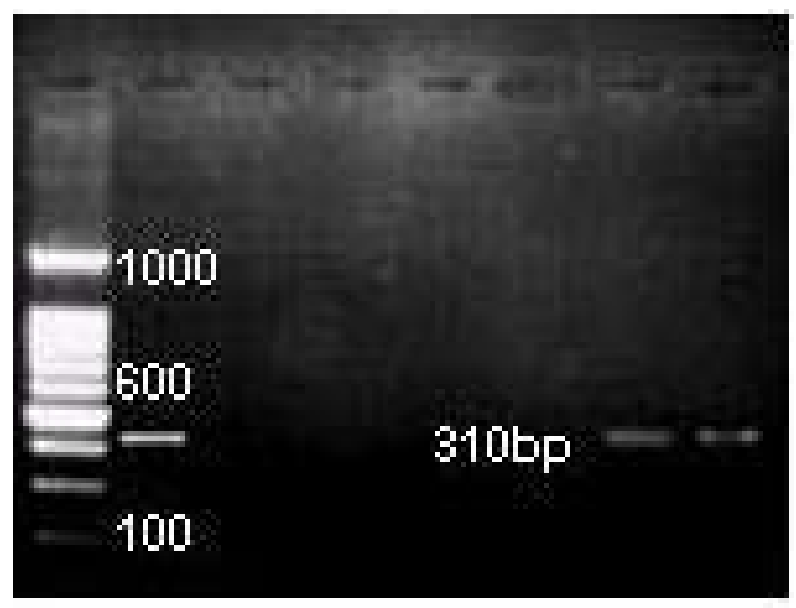

Fig. 1. PCR images of E.faecalis in root canal samples (1 positive control, 2 negative control, 3-7 root canal samples)

Fig. 2). No significant difference was observed in the comparison of the prevalence of these species in necrotic and root-filled teeth ( $p>0.05$; chisquared test). 


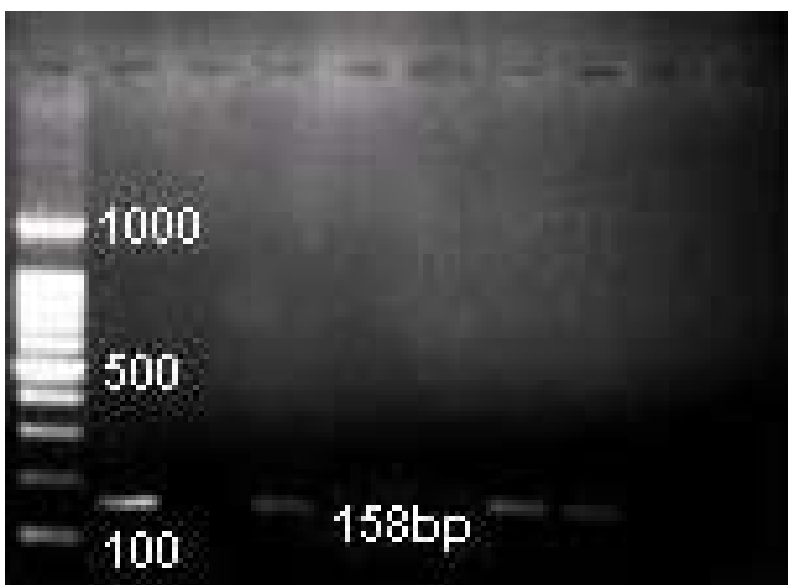

Fig. 2. PCR images of C.albicans in root canal samples (1 positive control, 2 negative control, 3-9 root canal samples)

\section{Discussion}

We have investigated the presence of E.faecalis and C.albicans in primary and secondary infected root canals. These microorganisms were found to be the most resistant species in the oral cavity to root canal treatment procedures, as shown in recent studies $(2,16)$, and they can survive in the challenging conditions of the root canal ecosystem $(3,27)$.

E.faecalis has been found in varying ratios in primary endodontic infections and root filled cases in previous studies (6). This wide diversity may be attributed to sample size, the quality of the initial treatment, the filling material, and different identification techniques $(9,20)$. Geographical differences in these studies may influence the results. For example, in refractory cases, E.faecalis was detected in $77 \%$ of cases in a Brazilian population (6), $64 \%$ of South Korean patients (8), $47 \%$ of a German population (25), $56 \%$ of Lithuanian patients (3), 72\% of Italian patients (26), and $30 \%$ of a North American population (27). On the other hand Ozbek et al. identified E.faecalis in $74.4 \%$ of root-filled teeth using real-time PCR east part of Turkey, which disagree with our results (28).

In recent years, PCR techniques have been increasingly used for the analysis of root canal flora (6-9). In PCR assays, it is not known whether the microorganisms detected can reproduce or survive (20). Molecular techniques can rapidly and accurately identify Enterococcus species with a higher sensitivity than can culturing from root canals. It may be expected that all teeth harbor microorganisms because periapical disease was present for all teeth. However, culturing and PCR showed a prevalence of microorganisms well below 100\% (26). Microorganisms may be present in the apical ramification and go undetected because they are covered by remaining root canal-filling material and therefore not soaked up by the paper point (26).

The results of this study showed that E.faecalis rate in retreatment was significantly lower than the previous studies $(8,28)$. Additionally, the E.faecalis prevalence was not statistically different between necrotic and retreatment cases. It is noteworthy that all examined samples contained bacteria. These findings were confirmed by amplification with 16S rRNA universal primers, which generated the predicted amplicon for all cases. Consistent with our results, some studies analyzing the microflora of root filled teeth with apical periodontitis have shown lower rates than in necrotic root canal therapy cases $(2,4)$. This may be caused by residual bacteria present in the accessory canals within the dentinal tubules, or it may be associated with the remnants of gutta perca, which may eventually prevent the sampling fluid from reaching the bacteria.

Another possible explanation may be the loss of bacteria during the sampling and cultivation procedures. In the study by Sassone et al. (1) and Ozbek et al. (29), samples were collected from the root canals using 15 Hedströentype files and paper points. In this study, the samples were taken only by paper points after reaming, which might reduce the amount of bacteria found in the root canal. If E.faecalis can penetrate deeply into the dentinal tubules, paper points may not be sufficient to sample this microorganism. However, Peter et al. (30) suggested that the reaming sampling technique did not improve recovery rates.

Ravazzi et al. (14) demonstrated that young subjects with good oral hygiene and no caries or inflammatory oral diseases do not ordinarily harbor enterococci in their oral cavities. Differences in findings between the present study and the previously mentioned studies may also be due to different dietary intake of, for example, cheese, because it has been reported that viable enterococci occur frequently and in high numbers in cheese (14). In another study we investigated E.faecalis in 17 different kinds of cheese consumed in Turkey by culture method. We didn't identify E.faecalis in any cheese samples (31).

The presence of yeast is more common in persistent infections after root canal preparations, probably due to contamination during treatment, or in cases of rootfilled teeth with therapy-resistant periapical lesions. In the present study, the prevalence of C.albicans was not statistically different between necrotic and retreated root canals $(\mathrm{p}>0.05)$.

Despite the lack of even minor evidence that Enterococ$c i$ are responsible for refrectory periapical inflammation, the endodontic community has apparently accepted a causal connection as fact. Molecular techniques are superior for sampling low numbers of bacteria and identifying very fastidious species. For more significant research on endodontic diseases using molecular techniques, safeguards and standardized procedures need to be established. Future studies should evaluate resistance 
profiles of C.albicans and E.faecalis isolated from root canals to the antiseptic agents used in dentistry.

In conclusion, within the limitation of this study, the results showed that C.albicans and E.faecalis were associated with root-canal infections in primary and secondary infections. These microorganisms may be potent pathogens in apical lesions; however, the present study does not provide strong evidence to support this hypothesis. Additionally, PCR analyses of teeth with periapical lesions revealed that the E.faecalis percentage was lower than rates found in previous studies, whereas the C.albicans prevelance was consistent with previous results.

\section{References}

1. Sassone L, Fidel R, Figueiredo L, Fidel S, Faveri M, Feres M. Evaluation of the microbiota of primary endodontic infections using checkerboard DNA-DNA hybridization. Oral microbiol immunol 2007;22:390-7.

2. Molander A, Reit C, Dahlen G, Kvist T. Microbiological status of root-filled teeth with apical periodontitis. Int Endod J 1998;31:1-7.

3. Peciuliene V, Balciuniene I, Eriksen HM, Happasalo M. İsolation of Enterococcus faecalis in previously root- filled canals in Lithuanian population. J of Endod 2000;26:593-5.

4. Sundqvist G, Fidor D, Persson S, Sjögren U. Microbiologic analysis of teeth with failed endodontic treatment and the outcome of conservative retreatment. Oral Surg 1998;85:86-93.

5. Siqueira JF. Endodontic infections: Concepts, paradigms, and perspectives. Oral Surg Oral Med Oral Path Oral Radiol Endodon 2002;94:281-93.

6. Roças IN, Jung IL-Y, Lee CY, Siqueira JF Jr. Polymerase chain reaction identification of microorganisms in previously root-filled teeth in a South Korean population. J of Endod 2004;30:504-508.

7. Gomes BPFA, Pinheiro ET, Sousa ELR, Jacinto RC, Zaia AA. Enterococcus faecalis in dental root canals detected by culture and by polymerase chain reaction analysis. Oral Surg Oral Med Oral Path Oral Radiol Endod 2006;102:247-53.

8. Siqueira JF Jr, Roças IN. Polymerase chain reaction-based analysis of microorganisms associated with failed endodontic treatment. Oral Surg Oral Med Oral Pathol Oral Radiol Endod 2004;97:8594.

9. Fouad AF, Zerella J, Barry J, Spanberg LS. Molecular detection of Enterococcus species in root canals of therapy-resistant endodontic infections. Oral Surg Oral Med Oral Pathol Oral Radiol Endod 2005;99:112-8.

10. Baumgartner JC, Siqueira JF Jr, Xia T, Roças IN. Geographical differences in bacteria detected in endodonti infections using polymerase chain reaction. J of Endod 2004;30:141-4.

11. Ray HA, Trope M. Periapical status of endodontically treated teeth in relation to the technical of the root filling and the coronal restoration. Int Endod J 1995;28;8-12.

12. Engström $B$. The significance of enterococci in root canal treatment. Odontol Revy 1964;15:87-104.

13. Sedgley CM, Buck G, Appelbe O. Prevalence of E.faecalis at multiple oral sites in endodontic patients using culture and PCR. J of Endod 2006;32:104-9.

14. Ravazzi A, Gmür R, Imfels T, Zehnder M. Recovery of Enterococcus faecalis from cheese in the oral cavity of healthy subjects. Oral Microbiol Immunol 2007;22:248-51.

15. Franz CM, Stiles ME, Schleifer KH, Holzapfel WH. Enterococci in foods: a conundrum for food safety. In J Food Microbiol 2003;88:105-22.

16. Siqueira JF Jr, Sen BH. Fungi in endodontic infections. Oral Surg Oral Med Oral Path Oral Radiol Endod 2004;97:632-41.

17. Arendorf TM, Walker DM. The prevalence and intra-oral dis- tribution of Candida albicans in man. Archives of Oral Biology 1980;25:1-10.

18. Siqueira JF Jr, Rocas IN, Oliveira JC, Santos KR. Molecular detection of black-pigmented bacteria in infections of endodontic origin. Jof Endod 2001;9:563-566.

19. Zoletti GO, Siqueira JF, Santos KRN. Identification of Enterococcus faecalis in root filled teeth with or without periradicular lesions by culture dependent and independent approaches. J of Endod 2006;8:722-26.

20. Baumgartner J.C. Microbiological and molecular analysis of endodontic infections. Endodontic Topics 2004;7:35-51.

21. Halse A, Molven O A strategy for the diagnosis of periapical pathosis. J of Endod 1986;12, 534-8.

22. Roças IN, Siqueira JF, Santos K.R.N, Coelho A.M.A. ' 'Red complex" (Bacteroides forsythus, Porphyromonas gingivalis, Treponema denticola) in endodontic enfections: A molecular approach. Oral Surg Oral Med Oral Pathol Oral Radiol Endod 2001;91, 468-71

23. Nandakumar R, Mirchandani R, Fouad A. Primer sensitivity: can it influence the results in Enterococcus faecalis prevalence studies? Oral Surg Oral Med Oral Path Oral Radiol Endod 2007;103:42932.

24. Kan VL Polymerase chain reaction for the diagnosis of candidemia. Infect Dis 1993;168, 779-83.

25. Roças IN, Hülsman M, Siqueira JF. Microorganisms in root canal treated teeth from a German population. J of Endod 2008;34:92631.

26. Schirrmeister J.F, Liebenow A.L, Braun G, Wittmer A, Hellwig E, Al-Ahmad A. Detection and eradication of microorganisms in rootfilled teeth associated with periradicular lesions: an in vitro study. $\mathrm{J}$ of Endod 2007;33:536-40.

27. Hancock HHI, Sigurdsson AD, Trope MB, Moiseiwitsch JB. Bacteria isolated after unsuccessful endodontic treatment in a North American population. Oral Surg Oral Med Oral Path Oral Radiol Endod 2001;91:579-586.

28. Roças IN, Siqueira JF, Santos KRN. Association of Enterococcus faecalis with different forms of periradicular diseases. J of Endod 2004; 30: 315-20.

29. Ozbek SM, Ozbek A, Erdogan AS. Analysis of enterococcus faecalis in samples from Turkish patients with primary endodontic infections and failed endodontic treatment by Real-time PCR SYBR Green method. J Appl Oral Sci 2009; 17,370-4.

30. Peters LB, Wesselink PR, Moorer WR. The fate and the role of bacteria left in root dentinal tubules. Int Endod J 1995;28:95-9.

31. Yoldas O, Dumani A, Akcimen B, Yilmaz S, Koksal F. Recovery of E.faecalis from Turkish cheese. 10 th İnternational Congress of the Turkish Endodontic Society. September 23-25, 2010. 